\title{
Influence of enzymes on the oil extraction processes in aqueous media
}

\author{
Guillaume RICOCHON \\ Lionel MUNIGLIA
}

LIBio,

Nancy Université INPL,

2, avenue de la Fôret-de-Haye,

BP 172, 54505 Vandœuvre-lès-Nancy,

France

<lionel.muniglia@ensaia.inpl-nancy.fr>

\begin{abstract}
The methods of oil aqueous extraction process (AEP) assisted by enzymes are, over the last 50 years, an alternative designed to replace traditional methods of extraction using organic solvents. To extract the oil using an AEP, the use of specific enzymes, able to hydrolyze some or all components of seeds, can significantly increase the yields of extraction. Hydrolyzing the different constituents of cell walls (cellulose, hemicellulose, pectins, proteins, etc.), enzymes are able to enhance the liberation of the oil. A number of physico-chemical parameters must also be considered for the better expression of the enzymatic mixture, while maintaining the quality of oils and meals. This article presents the various factors influencing the release of oil in aqueous media and the main results obtained by this process on various substrates.
\end{abstract}

Key words: oil aqueous extraction process, enzymes, quality

compounds in the water to increase. It is important to know the constituents of the plant cell walls to be able to choose which enzymes are to be used, and then among the families of chosen enzymes, to find the most efficient ones to finally define which factors allow to obtain the best yields.

\section{Cell wall constituents and specific enzymes}

To extract the lipid reserves stored in cells, it is necessary to be able to cross several barriers: first the extra cellular walls (or secondary cell walls), then the cell wall, and finally oleosomes. Each cell wall has its own constituents, sometimes organized in a complex structure, and synthesized and degraded in a natural manner by specific enzymes. For example, the secondary cell walls of rapeseeds are constituted of $39 \%$ pectins, 29\% hemicelluloses, 22\% cellulose, $8 \%$ of arabinogalactans (Dominguez et al., 1994) and constitute $20 \%$ to $28 \%$ of the total seed. The primary cell wall contains $10 \%$ of glycoproteins which are very rich in hydroxyproline, at first called extensins but called today HRGP (HydroxyProline Rich Glycoprotein).

Cellulose is a linear chain of several hundred to over nine thousand of $\beta$ - $(1 \rightarrow 4)$-linked D-glucose units. In the cell wall, the molecules of cellulose are assembled in parallel rows: microfibrils with a diameter from 5 to $12 \mathrm{~nm}$. They are constituted from 36 to 1,200 molecules of cellulose maintained together by hydrogen bonds between the hydroxyl groups of the nearby glucose residues. They are between 5 and $15 \mathrm{~nm}$ wide and separated from one to another by $20-40 \mathrm{~nm}$. Crystalline and amorphous domains can be observed.
Enzymatic degradation: the complete degradation of cellulose requires three types of enzymes: two cellulases (EC 3.2.1.4 and EC 3.2.1.91) and a $\beta$-glucosidase (EC 3.2.1.21). The first cellulase, called 1,4- $\beta$-cellobiosidase, is able to hydrolyse the intermolecular $\beta-(1 \rightarrow 4)$-glucosidic bonds. The second cellulase can hydrolyse the cellulose from the extremities of glucosidic chains; they consequently form either glucose or cellobiose. Finally, $\beta$-glucosidases can hydrolyse the cellobiose molecules, forming some glucose, to eliminate its inhibition on the other activities.

Hemicelluloses are linear or branched out polysaccharides bound to the celluloses microfibrils by hydrogen bonds or connected to the lignin by covalent bonds, so they form a complex and solid structure around plant cells. This complex polymer requires, as for the degradation of the cellulose, a set of enzymes able to work together. Oligosaccharides forming hemicelluloses are various and, consequently, many are the possible connections. Because enzymes are mostly specific for an unique type of bond, the use of a mixture of enzymes with different activities is required for the complete degradation of hemicelluloses. Shallom and Shoham (2003) published a review detailing the mode of action of the following hemicellulases:

Xylanases (EC 3.2.1.8) hydrolyse $\beta-1,4$ linked chains of xyloses, producing small xylooligomers. Lateral chains of glucuronic acids or of arabinoses fixed to this xylosidic skeleton can hide the action of these enzymes. Nevertheless, Hulbert et al. identified a xylanase which need the presence of 4-O-methyl-glucuronic acid to spot and break $\beta-1,4$-xylosidic links. 
$\beta$-Mannanases (EC 3.2.1.78) hydrolyse hemicelluloses composed of mannoses and liberate $\beta-1,4$-manno-oligomers, which can be then hydrolysed in mannose by $\beta$-mannosidase (EC 3.2.1.25).

$\alpha$-L-Arabinofuranosidases (EC 3.2.1.55) and $\alpha$-L-arabinanases (EC 3.2.1.99) hydrolyse hemicellulose constituted of arabinose. Some of these enzymes are not very specific to this substrate; they can act as well on the functional groups linked in 0-5, 0-2 and/or 0-3 of simple substituting, as on xylanes, xylo-oligomers and arabinanes substituted in O-2 and O-3 in two ways.

$\beta$-xylosidases (EC 3.2.1.37) are exoglycosidases which hydrolyse short oligomers in simple units of xyloses.

Hemicellulolytics ester hydrolases consist of the acetylxylan esterase (EC 3.1.1.72) which can hydrolyse acetyl and so substituting groups of xyloses, and feruloyl esterase (EC 3.1.1.73), which hydrolyse ester links between an arabinose and a ferulic acid, links allowing to link hemicelluloses to lignin.

Pectins are a linear chain of $\beta-(1 \rightarrow 4)$-linked D-galacturonic acid. Into this backbone, regions where galacturonic acid is replaced by (1-2)-linked L-rhamnose can be found. Lateral chains of neutral sugar can be attached to the rhamnose. The neutral sugars are mainly D-galactose, L-arabinose and D-xylose; the types and the proportions of neutral sugars vary with the origin of pectin. In nature, around $80 \%$ of carboxyl groups of galacturonic acid are esterified with methanol. The ratio of esterified to non-esterified galacturonic acid determines the fact pectins are classified as high- or low-ester pectins (HM or LM pectins), with more or less half of galacturonic acid esterified. Pectin ester hydrolases are also known as pectin methyl esterases. These enzymes catalyse the de-esterification of methoxyl groups forming pectic acids. These enzymes act in a preferential way on methyl esters of galacturonate units which are near the same non-esterified units. These actions on pectin chains prepare the substrate to supplementary enzymes.

Polymethylgalacturonases (PMG) catalyze the

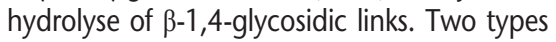
can be differentiated:

- Endo-PMG hydrolyses in an unpredictable way inside the pectin chain, with a priority for highly esterified pectin;

- Exo-PMG accomplishes sequential breaks in

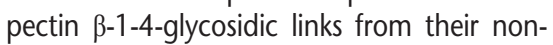
reducing end.

Polygalacturonases (PG) work in the same way as above (breakdown of $\beta$-1-4-glycosidic links), but on another substrate (acid pectin). In this group of enzymes, endo-PG [poly (1,4-a-D-galacturonide) glycanohydrolase] can be differentiated from exo-PG [poly (1,4- $\alpha$-D-galacturonide) galacturonohydrolase] enzymes.

\section{Proteins}

Proteases correspond to any enzyme which conducts proteolysis, that is to say, any enzyme which begins protein catabolism by hydrolysis of the peptide bonds linking amino acids together in the polypeptide chain. There are 5 types of proteases, classified according to their mechanism of action and amino acid (serine, threonine, aspartate, cysteine) or a metallic atom directly implicated in the mechanism. In theory, using proteases could be interesting for extracting oil. It would allow the proteins of cell wall structures to break, as well as oleosins, which stabilize oleosomes. Moreover, their use in an aqueous extraction process only promotes appearance and stabilization of the emulsions which they try to reduce.

\section{Parameters of extraction}

The enzymatic mix, the different parts of the process and the conditions under which the enzymatic attack is to be made are still not determined. This attack directly depends not only on $\mathrm{pH}$, temperature, quantity of used enzymes and hydrolysis time but also on the treatments before or after kernels enzymatic hydrolysis. The efficiency of enzymes will not be the same on the seeds, the meal or for the fine crushed kernels. Factors influencing extraction by enzymatic way are:

- grinding: type of crusher, speed, humid or dry;

- inactivation of endogenous enzymes: equipments, pH, humidity, temperature, time;

- water quantity and mixture: water/solid ratio, equipments, speed rate, time;

- enzymatic hydrolysis: time, agitation, enzyme/substrate ratio, $\mathrm{pH}$, temperature, sort of enzyme;

- inactivation of exogenous enzymes: temperature, $\mathrm{pH}$, time, equipments;

- oil recovery: centrifugation, filtering, speed rate, time, $\mathrm{pH}$, temperature.

It is also necessary to add to this list other treatments that the kernel, before enzymatic hydrolysis (pressing, for instance) or after enzymatic hydrolysis (pressing, extraction by solvent, etc.), can be subjected to.

Grinding: regarding the study of grinding in aqueous extraction process, it is possible to cite Rosenthal et al. (1998) who put in an obvious place the effect the level of crushing has on the yield of extraction in oil and in protein; more thin is the crushing, more are the cell walls destroyed, and better are the yields. This study allows even to conclude that the effect of enzymes on soya is insignificant in comparison with the role of the particle size - without enzyme, the oil extraction yield resulting from an extraction in aqueous media ranged from $28 \%$ to $66 \%$ where the size of the particles of soya varied from 150 to $850 \mu \mathrm{m}$. The same results are obtained on germ corn (Dickey et al., 2008).

Endogenous/exogenous enzymes inactivation: it is necessary to preserve oil quality to disable a lot of endogenous enzymes such as myrosinase or lipase before the aqueous extraction. For myrosinase, Van Eylen et al. (2006) investigated the thermal inactivation kinetics of mustard seeds myrosinase in intact tissue: enzymatic activities are not detected at $72.5^{\circ} \mathrm{C}$ after $30 \mathrm{~min}$ or at $75^{\circ} \mathrm{C}$ after $10 \mathrm{~min}$. The authors have shown that the time of treatment decreased when the seeds are not intact. Boiling intact rapeseed for 5 min can inactivate myrosinases effectively and $11.28 \%$ of glucosinolates is degraded due to the heating (Zhang and Wang, 2006). The inactivation by heating in an aqueous media is easier than in the whole seed (at $90^{\circ} \mathrm{C}$, the reference temperature). The authors have also shown that inactivation of rapeseed lipase is better with a microwave treatment than with a steam heating. And finally, the free fatty acid (FFA) content increases with the time of treatment but is the same in both cases (microwave vs. steam heating).

Water quantity and mixture: an optimum solid/ water ratio was established by Sineiro et al. (1998) on sunflower at 7.5-8 g water per gram of seeds, whereas Hagenmaier (1974) worked with 1:10. For peanut oil extraction, solid:water ratios recommended in the literature vary from 1:5 to 1:12. Embong and Jelen (1980) reported an optimum ratio varying between 1:2.5 and 1:3.5 for rapeseed oil extraction. In fact, the two different ways are opposite: for generating less effluent and less stable emulsion, it is necessary to have a high solid/water ratio in the extraction step. However, to obtain the highest extraction rates and extraction yields, it is usually necessary to use large quantities of water. The differences between these ratios come certainly from the cell wall composition, but also from different equipments of extraction and agitation.

\section{Importance of enzymatic mixture}

The enzymes, presented in the first part, were tested alone or in combination on numerous substrates, such as soya (Adler-Nissen, 1986; Yoon et al., 1991; Olsen, 1982; Bargale et al., 2000), corn (Bocevska et al., 1993), olive (Fantozzi et al., 1977; Ranalli and Martinelli, 1994), coconut (McGlone et al., 1986; Christensen, 1989), avocado (Buenrostro and Lopez-Munguia, 1986; Freitas et al., 1993), sunflower (Lanzani et al., 1975; Dominguez et al., 1995, 1996), palm (Cheah et al., 1990), rice bran (Hanmoungjai et al., 2000) and peanuts (Jiang et al., 2010). The results obtained on extraction yields vary. However, they all 
come down to the same idea that the selection of multi-activity enzymes is always the most competitive, because as different polymers of the plant walls overlap, the effect of an enzyme will favour the release of a substrate of another enzyme (shown by Mathlouthi et al. (2002) on numerous substrates, including soybean, sunflower and rapeseed meals with xylanase and $\beta$ glucanase). So, the more important the number of enzymatic activities in media, the quicker and the more complete the hydrolysis of cell walls. However, any general implementation of an optimum mixture is impossible, as each species and each variety has different parietal compositions. The knowledge of the composition of the kernel or fruit cell walls must allow an enzymatic activity mixture to be composed in the same proportions in favouring a particular type of activity, because its substrate is in a bigger or smaller proportion.

Different studies on rapeseed about enzymatic mix have documented the results summarized in table 1.

Following Lanzani's results, it was realized that the addition of pectinase could increase the yields to $4 \%$. Sosulski also increased his yield by adding activities to a pectinolitic mixture. Therefore, the number of enzymatic activities which are present in the mix is very important. All these factors have a real importance on

enzymatic hydrolysis and free oil yield, and on oil and proteins quality as well as on the quantity of emulsion obtained after treatment. They can therefore produce some oil, but it necessary to minimize emulsion, by supporting the quality of oil and of protein.

\section{Oil quality}

Zhang et al. (2007) developed an interesting study of oil quality. Indeed, compared to solvent-extracted oil, enzyme-extracted oil contains more free fatty acids while its peroxide value is lower. The colour of enzyme-extracted oil is slightly darker than solvent-extracted oil's. The iodine value, the saponification value and fatty acid composition are similar. Protein hydrolysates are composed of about $96 \%$ of peptides smaller than 1,500 Da, among about $87 \%$ are less than $600 \mathrm{Da}$. Protein hydrolysates are purified by macroporous adsorption resins. The sugar and ash contents of protein hydrolysates are significantly reduced and no glucosinolates or phytic acids are detected after purification.

\section{Emulsion}

Emulsion is necessary to get a good yield in free oil. To control emulsion, parameters which favour the water/oil mix (quantity of water,

Table 1. Yields of aqueous enzymatic process on rapeseed.

\begin{tabular}{|c|c|c|c|c|}
\hline Enzyme & Temperature $\left({ }^{\circ} \mathrm{C}\right)$ & Time (h) & $\begin{array}{l}\text { Extraction } \\
\text { yield }\end{array}$ & References \\
\hline Protease & $40-50-65$ & 3 & $74 \%$ total oil & Lanzani et al., 1975 \\
\hline $\begin{array}{l}\text { Protease } \\
\text { Pectinase }\end{array}$ & $40-50-60$ & 3 & $78 \%$ total oil & Lanzani et al., 1975 \\
\hline $\begin{array}{l}\alpha \text {-amylase } \\
\beta \text {-glucanase } \\
\text { Protease }\end{array}$ & $50-63$ & 3 & $72 \%$ total oil & Fullbrook, 1982 \\
\hline Hemicellulase & $50-53$ & 3 & $75 \%$ total oil & Fullbrook, 1982 \\
\hline Multi-activity & 50 & 12 & $43 \%$ dry matter & Sosulski et al., 1988 \\
\hline Pectinase & 50 & 12 & $39 \%$ dry matter & Sosulski et al., 1988 \\
\hline Multi-activity & $45-50$ & 6 & Not determined & Sosulski and Sosulski, 1990 \\
\hline Multi-activity & 50 & 4 & Not determined & Olsen, 1988 \\
\hline Multi-activity & Not determined & Not determined & $80 \%$ total oil & Deng et al., 1992 \\
\hline $\begin{array}{l}\text { Pectinase } \\
\text { Cellulase } \\
\beta \text {-glucanase } \\
\text { Protease }\end{array}$ & 48 & 3 & $83 \%$ total oil & Zhang et al., 2007 \\
\hline $\begin{array}{l}\text { Pectinase } \\
\text { Cellulase } \\
\beta \text {-glucanase } \\
\text { Protease }\end{array}$ & 48 & 5 & $88-90 \%$ total oil & Zhang and Wang, 2006 \\
\hline
\end{tabular}

agitation), as well as the parameters which support the stability of mixture (surfactant), are required. This is the case with proteases which produce peptides, and are well known for their amphiphilic property.

Guillemin (2006) made proteases act on rapeseed and has acquired yields close to those found by Zhang in 2007. However, the majority of oil is contained in the emulsion, and it has been proved that it is impossible to clear (with testing physical-chemist, thermodynamics or ultrasound way) the emulsion.

\section{Conclusion}

Many researchers have worked on oil extraction in aqueous media, with and without enzymes. Many seeds or fruits have been studied over the last 50 years.

Why this research lasts so long and why this work should be continued?

The research lasted so many years for a very simple reason. The process of extraction with hexane always provides the best returns. With more than $96 \%$ of oil recovered, these processes are almost perfect. Three important reasons can question the use of hexane:

- air pollutant;

- dangerousness;

- cost.

These three aspects make the research around this issue persists to this day. The alternative extraction techniques are improved or created regularly: the $A E P$, the supercritical $\mathrm{CO}_{2}$ extraction, etc.; without ever reaching for the moment, the process returns to hexane extraction.

Thus, these processes remain incomplete and do not always grow at an industrial scale. Why research is still continued in this track?

Because these alternative procedures, including the AEP, are still promising. For further extraction of oil, which yields steady progress for years, we can notice that many publications in the area also speak of the extraction of proteins, which are recoverable by-products, while it is more difficult in the case of existing processes.

If high oil yields are reached and the extracted proteins are good, then the AEP may be an economically viable process of extraction. They will be industrially interesting, especially since the oil produced, if they do not achieve sufficient returns, have qualities superior to those obtained by processes using solvents. The conclusions of main publications on this subject show several points repeatedly:

- the specific substrates and enzymes used; - the importance of enzymes and their conditions of employment (specific activities, duration, $\mathrm{pH}$, temperature, ratio of seed/water ratio of enzyme/seed); 
- the pre-hydrolysis treatment (cleaning, grinding, inactivation of endogenous enzymes);

- and separation techniques.

By setting these factors, and studying their influence and importance on the AEP, it is probably possible to achieve economically attractive yields.

\section{REFERENCES}

Adler-Nissen J. A review of food protein hydrolysisspecific areas. In: Adler-Nissen, ed. Enzymic Hydrolysis of Food Proteins. London and New York: Elsevier Applied Science Publishers, 1986.

Bargale PC, Sosulski K, Sosulski FW. Enzymatic hydrolysis of soybean for solvent and mechanical oil extraction. J Food Process Engineer 2000; 23: 321-7.

Bocevska M, Karlovic D, Turkulov I, Pericin D. Quality of corn germ oil obtained by aqueous enzymatic extraction. / Am Oil Chem 1993; 70: 1273-7.

Buenrostro M, Lopez-Munguia CA. Enzymatic extraction of avocado oil. Biotechnol Left 1986; 8: 505-6.

Cheah SC, Augustin MA, Ooi LCL. Enzymic extraction of palm oil. Palm Oil Res Malaysia Bull 1990; 20: 30-6.

Christensen FM. Enzyme technology versus engineering technology in the food industry. Biotechnol Appl Biochem 1989; 11: 249-65.

Deng Y, Pyle D, Niranjan K. Studies of aqueous enzymatic extraction of oil from rapeseed. In: Agricultural engineering and rural development I. Conference Proceedings, 1992.

Dickey L, Kurantz M, Parris N. Oil separation from wet-milled corn germ dispersions by aqueous oil extraction and aqueous enzymatic oil extraction. Ind Crop Prod 2008; 27: 303-7.

Dominguez $\mathrm{H}$, Nunez M, Lema J. Aqueous processing of sunflower kernels with enzymatic technology. Food Chem 1995; 53 : 427-34.

Dominguez H, Sineiro J, Nunez M, Lema J. Enzymatic treatment of sunflower kernels before oil extraction. Food Res Int 1996; 28 : 531-45.
Dominguez H, Nunez M, Lema J. Enzymatic pretreatment to enhance oil extraction from fruits and oilseeds: a review. Food Chem 1994; 49: 271-86.

Embong MSB, Jelen P. Sulfur content of crude rapeseed oil from aqueous extraction. J Am Oil Chem Soc 1980; 57: 75-6.

Fantozzi P, Petruccioli G, Montedoro G. Enzymatic treatment of olive pastes after single pressing extraction. Effect of cultivar, harvesting time, and storage. Rils Ital Sosfanze Grusse 1977; 54: 381-8.

Freitas SP, Lago RCA, Jablonka FH, Hartman L. Aqueous enzymatic extraction of avocado oil from fresh pulp. Rev Fr Corps Gras 1993; 40: 365-71.

Fullbrook PD. The use of enzymes in the processing of oilseeds. J Am Oil Chem 1982; 60: 476-8.

Guillemin S. Extraction aqueuse d'huile de colza assistée par hydrolyse enzymatique : optimisation de la réaction, caractérisation de l'émulsion et étude des procédés de destabilisation. Thèse de I'Institut National Polytechique de Lorraine, 2006.

Hagenmaier R. Aqueous processing of full-fat sunflower seeds: Yields of oil and protein. J Am Oil Chem Soc 1974; 51: 470-1.

Hanmoungjai P, Pyle L, Niranjan K. Extraction of rice bran oil using aqueous media. / Chem Tech Biot 2000; 75: 348-52.

jiang L, Hua D, Wang Z, Xu S. Aqueous enzymatic extraction of peanut oil and protein hydrolysates. Food Bioprod Process 2010; 88: 233-8.

Johnson LA, Lusas W. Comparison of alternative solvents for oils extraction. J Am Oil Chem Soc 1983; 60: 229-42.

Lanzani A, Petrini M, Cozzoli O, Gallavresi P, Carola $C$, Jacini $G$. On the use of enzymes for vegetable-oil extraction. A preliminary report. Riv Ital Sostanze Grasse 1975; 11: 226-9.

Mathlouthi N, Saulnier L, Quemener B, Larbier M. Xylanase, $\beta$-glucanase, and other side enzymatic activities have greater effects on the viscosity of several feedstuffs than xylanase and $\beta$-glucanase used alone or in combination. J Agr Food Chem 2002; 50: 5121-7.
McGlone OC, Lopez-Munguia CA, Cater JV. Coconut oil extraction by a new enzymatic process. Food $\mathrm{Sci}$ 1986; 51: 695-7.

Olsen H. Aqueous extraction of oil from seeds. In: Asian food conference, Bangkok, 1988.

Olsen HS. Method of producing soy protein hydrolysate from fat-containing soy material, and soy protein hydrolysate. U.S. patent $4.324 .805 ; 1982$.

Ranalli A, Martinelli N. Extraction of the oil from olive pastes by biological and not conventional industrial techniques. Industrie Alimentari 1994; 33: 1073-83.

Rosenthal A, Pyle D, Niranjan K. Aqueous and enzymatic processes edible oil extraction. Enzyme Microb Tech 1996; 19: 402-20.

Rosenthal A, Pyle D, Niranjan K. Mechanisms in the simultaneous aqueous extraction of oil and protein from soybean. Food Bioprod Process 1998; 76: 224-30.

Shallom D, Shoham Y. Microbial hemicellulases. Curr Opin Microbiol 2003; 6: 219-28.

Sineiro J, Domínguez $H$, Núñez MJ, Lema JM. Optimization of the enzymatic treatment during aqueous oil extraction from sunflower seeds. Food Chem 1998; 61: 467-74.

Sosulski K, Sosulski F, Coxworth E. Carbohydrase hydrolysis of canola to enhance oil extraction with hexane. I Am Oil Chem 1988; 65: 357-61.

Sosulski K, Sosulski F. Enzyme pretreatment to enhance oil extratability. Amsterdam: Elsevier, 1990.

Van Eylen D, Indrawati M, Hendrickx M, Van Loey A. Temperature and pressure stability of mustard seed (Sinapis alba L.) myrosinase. Food Chem 2006; 97: 263-71.

Yoon SH, Kim LH, Kim SH, Kwon TW. Effects of enzyme treatments and ultrasonification on extraction yields of lipids of protein from soybean by aqueous process. Korean J Food Sci Technol 1991; 23: 673-6.

Zhang S, Wang Z. Aqueous enzymatic extraction of rapeseed emulsified oil. Nongye Gongcheng Xuebao/ Transactions of the Chinese Society of Agricultural Engineering $2006 ; 22$ : 250-3

Zhang S, Wang Z, Xu SY. Optimization of the aqueous enzymatic extraction of rapeseed oil and protein hydrolysates. J Am Oil Chem 2007; 84: 97-105. 